\title{
ANALYSIS OF FLOOD DISTRIBUTION IN SUB-WATERSHED BENDUNG BY USING GEOGRAPHIC INFORMATION SYSTEM (GIS)
}

\author{
Rully Marinto $^{1}$, Ngudiantoro $^{2}$, Ari Siswanto ${ }^{3}$ \\ ${ }^{123}$ Environmental Management Department, Graduate School of Sriwijaya University \\ *e-mail: rullymarinto@gmail.com
}

\begin{abstract}
The research was conducted to map the level of flood vulnerability in the area around Sub DAS Bendung and Analyzing the influence of natural factors causing flood and land cover factors on flood vulnerability in the area around Sub DAS Bendung. In the rainy there are floods in some locations. The Flood of Sub DAS Bendung are influenced by several factors including natural factors such as river characteristics, which have small river channel capacity, some areas that are swamp, sea tides that resist the flow of a river, and relatively flat topography conditions, so some Sub DAS Bendung area is a floodplain. Studies of the main causes of flooding in Palembang City or in other areas are very important. The use of GIS as an analytical tool will make it easier to examine the factors causing flooding to classify areas with high flood vulnerability. Thus expected to provide solutions and reduce the impacts caused by floods.
\end{abstract}

Keywords: Flood; Geographic Information System; Bendung.

\section{INTRODUCTION}

In the city of Palembang, the problem of flood inundation has been at a serious stage, with periods of flood inundation varying between 1 to 12 hours and even more in some regions. In addition to topographic factors, the city's economic growth and urbanization have resulted in the development of Palembang's urban areas to the low-lying areas prone to flooding. The development area of this city has even experienced repeated flooding. This pool caused damage to property, public infrastructure and traffic disruptions (Palembang City Bappeda, 2003).

The problem of water and land resource management is closely related to the level of need fulfillment, the existence of the quality and quantity of its extent and its cycle of use and how it is managed, including in the flood prevention and mitigation approach. Therefore required some formulation such as Coordinated understanding is needed in a strategy to manage land and water resources related to their utilization; Strategies and policies are required that take into account several approaches and mitigation of flood potential in the context of sustainable regional and environmental development (Sebastian, 2008)

Musi River is a large river that divides the Palembang City into two areas, namely Seberang Ulu and Seberang Ilir. The Musi River also has small rivers that also serve as urban drainage. The surface of the Musi River is influenced by tidal seawater, where during the dry season there is a decrease in river flow so that the river water level reaches the minimum height. In tidal conditions, the entry of sea water can reach 54 $\mathrm{km}$ upstream from the coast, so that in the rainy season with large bulk followed by rising tide, then almost most of Palembang area inundated with water (Heryana, 2004).

The location of this research is SubDistrict Kemuning located in Sub DAS Bendung. This location belongs to the Drainage 
Area I, which influenced by the tides of the Musi River. At this time, the condition of Sub DAS Bendung is quite apprehensive. In the rainy, there are floods in some locations. This becomes a routine problem faced by the Government of Palembang.

The Flood of Sub DAS Bendung are influenced by several factors including natural factors such as river characteristics, which have small river channel capacity, some areas that are swamp, sea tides that resist the flow of the river, and relatively flat topography conditions, so some Sub DAS Bendung area is a floodplain. According to research Novianti (2011) study of the main causes of flooding in the city of Palembang or in other areas is very important. The use of GIS as an analytical tool will make it easier to examine the factors that cause flooding to classify areas that have high levels of flood vulnerability. This is expected to overcome and reduce the impacts caused by the flood disaster Heryana (2012) states that Palembang and the surrounding areas there are many slums, especially alongside the river areas, the land is located in the wetlands area in Palembang.

Geographic Information System (GIS) as a useful tool for handling spatial data and storing digital formats. Geographic Information System (GIS) can also be used as the main tool that is interactive, interesting, and challenging in efforts to improve understanding, understanding, learning about the concept of location, space (spatial), demography and geographical elements contained in the earth's surface and related attribute data that accompany it (Edi Iskandar, 2012).

\section{MATERIALS AND METHODS}

The research location is located in Sub DAS of Bendung, which is in Kemuning SubDistrict of Palembang City, South Sumatera Province. Using layered spatial analysis method, integrating remote sensing data analysis, evaluation of coverage and land use and analysis of rainfall and river flow by using Geographic
Information System application and HEC-RAS for Hydrology analysis.

Multi temporal classification analysis was performed using an image intended to identify the rate of land change that occurred. Land change Analysis using post classification comparison change detection method, that is by performing multi temporal classification process in parallel which then compared together, inundated so that obtained information of land changes which happened after previously both form of output is put into a table "Confusion Matrix". Digital Elevation Model (DEM) is processed to illustrate the topography of the earth's surface so it can be visualized into 3D (Three Dimensional) view. While SRTM (Shuttle Radar Topographic Mission) is processed to create topographic data (DEM). The DEM-SRTM data is extracted using GIS software into Elevation and Slope data.

The elevation data in this study is divided into 2 kinds, height data taken from the ground surface that reflects the height of the soil surface and elevation data taken from the surface of the river that reflects the height of the river water. Furthermore, the altitude data is converted into DEM ground surface and DEM surface of the river.

The calculation of flood discharge by the rational method requires rainfall intensity data. A high intensity of rain in general with a short duration and covering a narrow area. The rain that covers a large area, rarely with high intensity, but can last for a long duration.

The natural character of flood potential is influenced by rainfall character and watershed morphometry (watershed shape, river gradient, drainage density, mean slope of the watershed). Rain is the main hydrological input in the watershed hydrological system. The rain that occurs above normal makes the river riverbed unable to accommodate all the rain water that goes down so that the surrounding area is inundated. The shape of the watershed gives a different effect on flood vulnerability. Physical parameters of watersheds in addition to rainfall 
that affect flood vulnerability are watersheds, river gradients, drainage density, and average river basin slopes.

\section{RESULT AND DISCUSSION}

In this research Bendung Sub-DAS is divided into several areas to know the boundary of catchment area that enters the Bendung river, which then created a scheme for the hydrological and hydraulic models of the river weir. Determination of catchment area boundaries from the research location was determined based on topographic maps in the form of digital elevation models (DEM). Catchment Area in Image analysis and SRTM Map with the help of the Global Mapper program. This DEM map is made with a $5 \mathrm{~m} \times 5 \mathrm{~m}$ resolution. Data from high point maps and contour maps are then analyzed using the create elevation grid command from $3 \mathrm{D}$ vector data to produce topographic maps show in Figure 1 below.

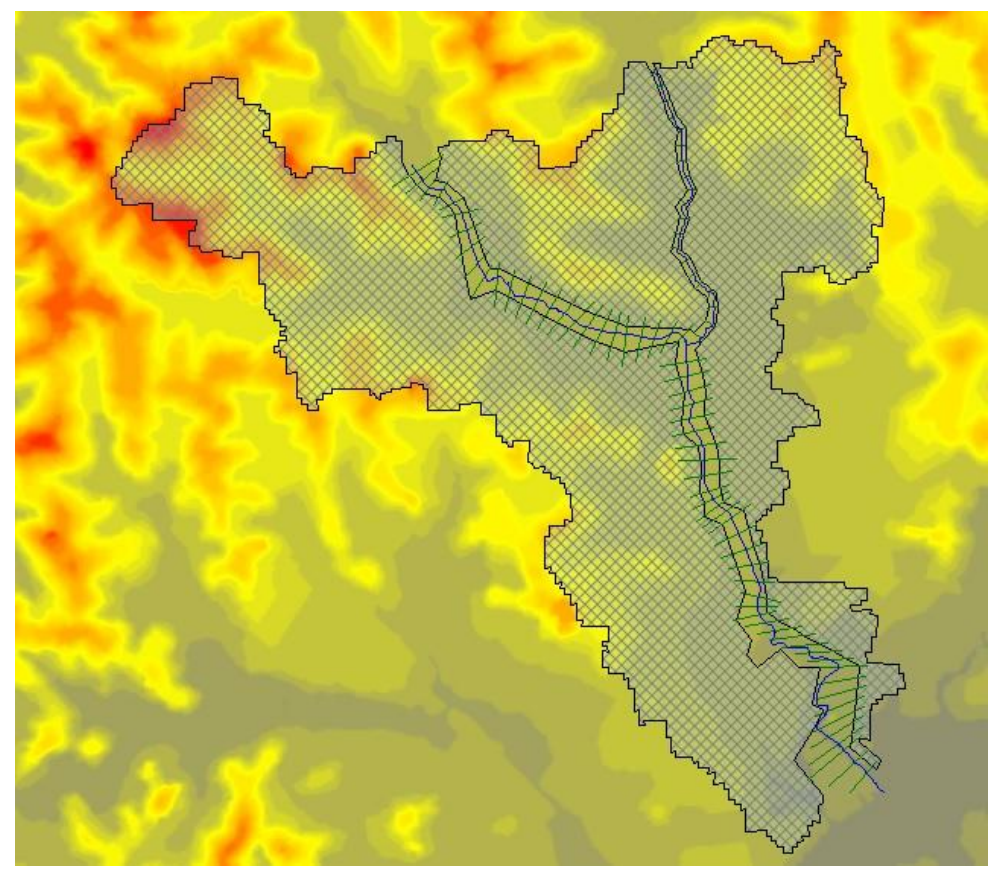

Figure 1. Catchment Area Boundary of Sungai Bendung (Self Documentation use Global Mapper) (Doc. 2018).

There are 3 (three) ways to calculate the average rainfall, namely the average algebraic method, the Thiessen Polygon Method, and the Isohyet Method in the study using the Thiessen method. This method takes into account the weight of each station that represents the area around it. In an area within the watershed, it is considered that rain is the same as that which occurs at the nearest station so that the rainfall recorded at a station represents that area. This method is used if the spread of rain stations in the area is not evenly distributed, in this method the minimum rainfall station used for calculation is three rain stations (Cambodia, 2015).

The average rainfall count is done by calculating the area of influence of each station. the Thiessen polygon method is used. this method is used because there are several rain observation stations that may affect the research area, namely Tridinanti, Gandus, and Kenten. Rainfall data is the result of measurement from Tridinanti rain observation station. the data used in the form of maximum rainfall during the last 14 years, starting from 2002 until 2015, obtained from BMKG Palembang. 
Table 1. Daily maximum rainfall

\begin{tabular}{cc}
\hline Tahun & $\mathbf{R}_{\text {maks }}(\mathbf{m m})$ \\
\hline 2002 & 215 \\
2003 & 114 \\
2004 & 96 \\
2005 & 114 \\
2006 & 121 \\
2007 & 84 \\
2008 & 114 \\
2009 & 102 \\
2010 & 133 \\
2011 & 130 \\
2012 & 133 \\
2013 & 108 \\
2014 & 111 \\
2015 & 116 \\
\hline
\end{tabular}

(Ref : BMKG Kenten, 2015)

The relationship between intensity, duration of rain and rain frequency, usually expressed by the Intensity-Duration-Frequency (IDF) curve. IDF analyzes are carried out to predict peak discharge in small catchments. to form an IDF curve, rainfall data with a short duration required (5 minutes, 10 minutes, 20 minutes and so on). At the modeling stage, water level analysis using HEC-RAS software. Several stages are the river geometry drawing, river hydraulics drawing and results in presentation. From that systematic step by using software we can get map scheme bendung river That show in figure 2 Bendung river scheme using HEC-RAC software.

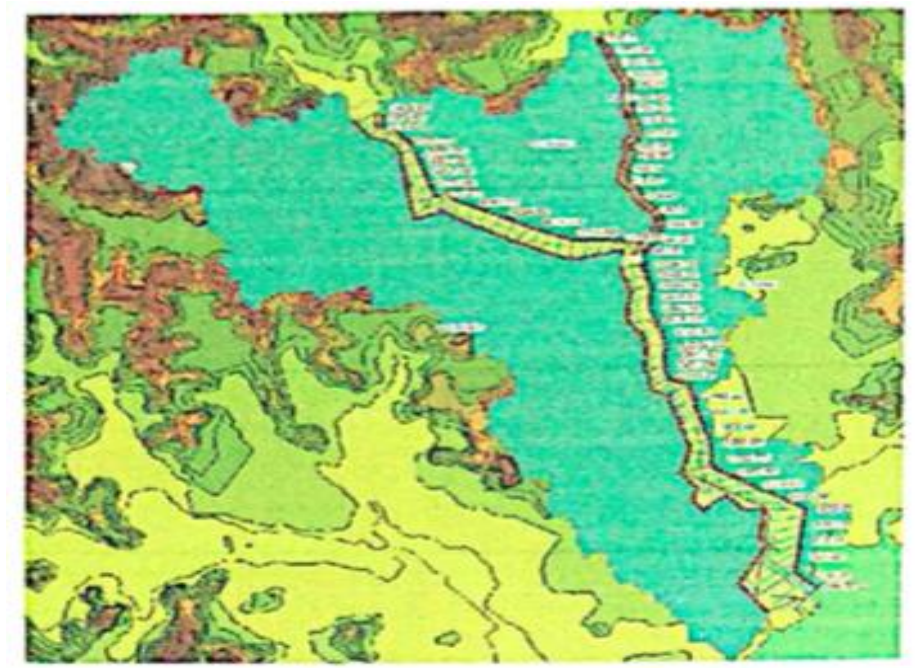

Figure 2. Bendung river scheme using HEC-RAS software (doc. 2018)

Land Altitude In the Catchment Area, the City of Palembang in general is a lowland with an average altitude of \pm 4 - 12 meters above sea level, with a composition: $48 \%$ of the plains are not flooded, $15 \%$ of the soil is submerged seasonally and $35 \%$ of the soil is stagnant continuous throughout the season. From the results of the SRTM Map process, we obtain the Land Level in the Catchment Area which is depicted in the figure below. The result of water level analysis using HEC-RAS, states the characteristic of flood inundation for maximum water flow is as shown in figure 3 . 

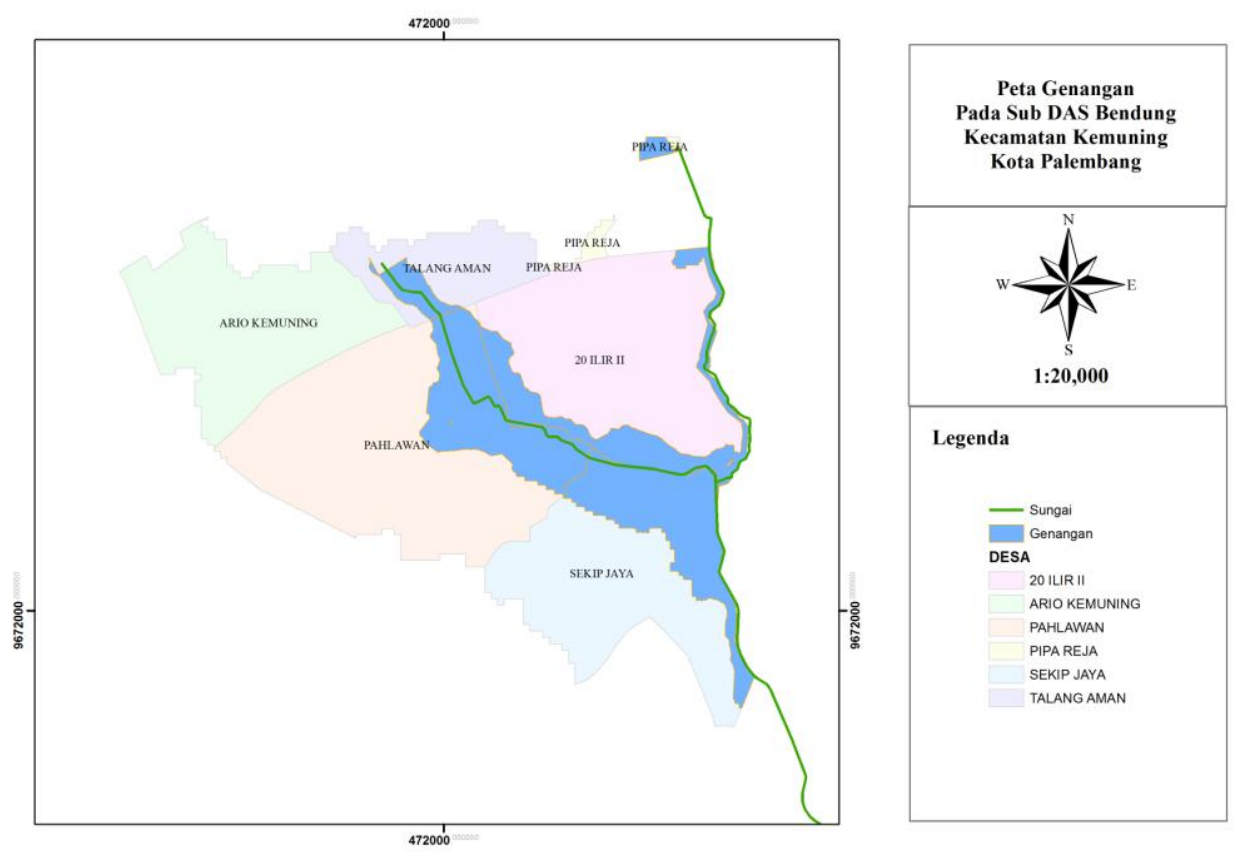

Figure 3. Flooded areas (doc, 2018)

From the simulation results using software, the flooded area obtained due to the maximum discharge is $166.89 \mathrm{Ha}$, or $18.69 \%$ of the total area of the watershed, with a flood depth ranging from 0-2.205 $\mathrm{m}$ (Figure 4) accoding to Asdak (2004) its cause by the increase in population, industrial growth, urban development and development, traffic density, deforestation and other causes, the population density on the riverbanks will be higher year by year. A lot of land conversion on the banks of the river is a densely populated settlement, which is one of the causes of flooding because the river will experience silting and narrowing because of the increasing amount of sedimentation and waste.

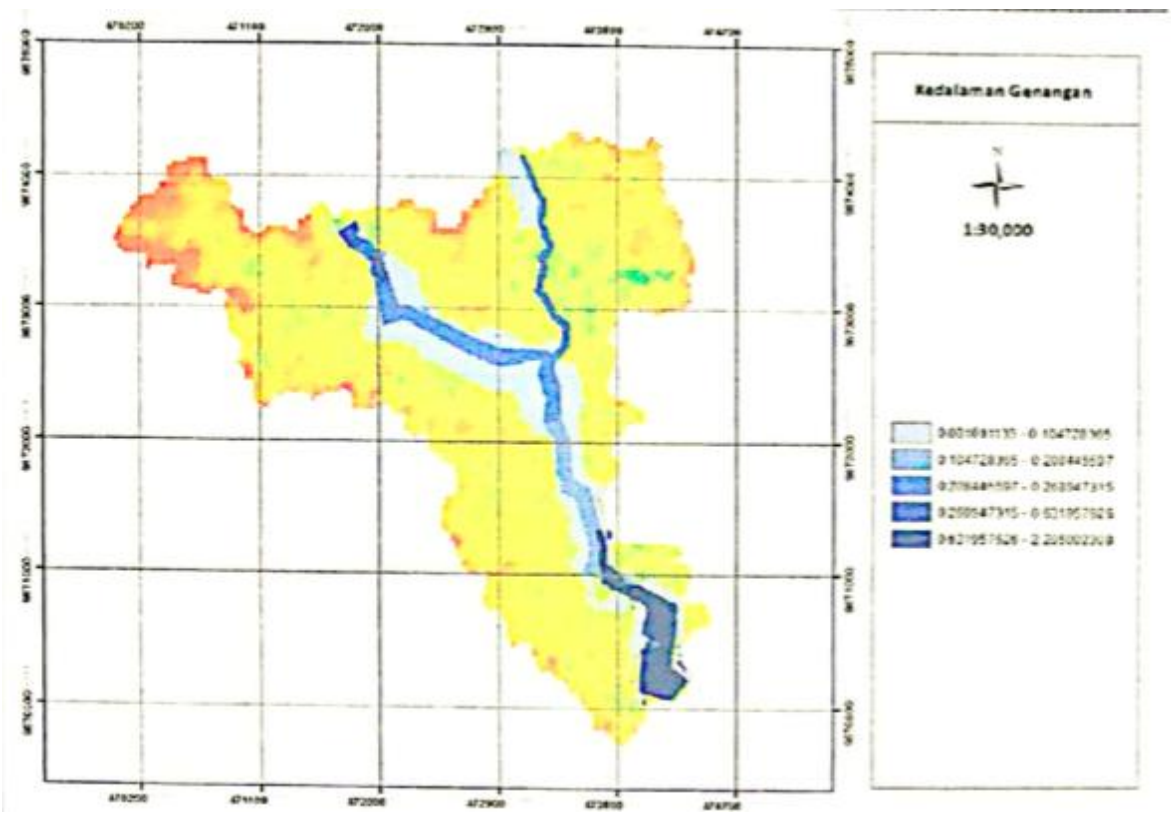

Figure 4. The depth of the flood (doc. 2018)

The extent of the inundation coverage and inundation depth in the Sub-watershed ofendung, which can be described in the Data Overlay, was conducted to provide a relationship between one 
aspect of the causes of flooding and other aspects. In the figure above (Figure 4), inundation data is overlaid with land use data in villages affected in Kemuning sub-district. The results of overlaying inundation and land use data results from the overlay between inundation data and land use data, it was found that inundation inundated residential areas located on the banks of the river.

Land use for settlements in each village is the land that suffers the most from flooding. If seen in Figure below, Kemuning Subdistrict is indeed a Population-Solid Settlement that has a fairly evenly held surface height. Rosyidie, (2013) state that the problem of watershed management is increasingly complex because not a few local governments do not understand the concept of ecosystem-based watershed management and across administrative boundaries. A more emphasis on economic aspects such as Regional Original Income (PAD) causes the concept of integrated watershed management that prioritizes ecosystem conservation to be neglected.

\section{CONCLUSIONS}

1. Based on the results of the analysis and simulation for flood flows in the Bendung drainage system with the 2D flow model, the maximum condition of the inundation area is $166.89 \mathrm{Ha}$, with a depth of 0-2.205 $\mathrm{m}$.

2. Natural factors such as rainfall, land topography, and land cover are very influential on the vulnerability of floods that occur. The density of settlements on the riverbanks and the low topography in the area will make the area around the Bendung Sub-watershed continue to experience flooding.

3. Another effect of population density around the river flow is to accumulate waste, which will also inhibit river flow.

\section{REFERENCES}

[1] Asdak. C. 2004. Hidrologi dan Pengelolaan daerah Aliran Sungai. Gajahmada University Press. Yogyakarta.

[2] Bappeda Kota Palembang. 2003. Perencanaan Masterplan Drainase dan DED DAS Bendung Kota Palembang.

[3] Badan Meteorologi, Klimatologi, dan Geofisika. 2015. Jumlah Curah Hujan dan Jumlah Hari Hujan di Stasiun Pengamatan BMKG, 2011-2015. Palembang.

[4] Cambodia, Mirnanda, 2015, Daily Rainfall Stochastic Model from several Rainfall Stations in Way Jepara.

[5] Haryani., Nanik. S., Any. Z., Dede. D., Hidayat. FY., \& Junita P. 2012. Jurnal Penginderaan Jauh : Model Bahaya Banjir Menggunakan Data Penginderaan Jauh Di Kabupaten Sampang.

[6] Heryana, A. 2015, Journal of Sustainable Development, Flood Hazard Analysis as Impact of Climate Change on Slum Areas in Palembang, South Sumatera.

[7] Novianti, H. 2011. Studi Pemanfaatan Lahan Kota Palembang Pada Sub DAS Bendung Untuk Penanganan Banjir. Program Pasca Sarjana Universitas Sriwijaya.

[8] Rosyidie. A. 2013. Banjir: Fakta dan Dampaknya, Serta Penngaruh dari Perubahan Guna Lahan, Jurnal Perencanaan Wilayah dan Kota, Vol. 24 No. 3, Desember 2013, hlm.241 249.

[9] Surbakti. H. 2012. Jurnal Penelitian Sains : Karakteristik Pasang Surut dan Pola Arus di Muara Sungai Musi, Sumatera Selatan.

[10] Sebastian, L. dan S. E. Rahim, 2011. Strategi Pengendalian Limpasan Permukaan (Runoff), Tunas Gemilang, Palembang.

[11]Sebastian, Ligal, 2008, Pendekatan Pencegahan Dan Penanggulangan Banjir Tunas Gemilang, Palembang. 